\title{
A Response to "Intrinsic vs Extrinsic Motivation as Drivers for Early Engagement in Research by Medical Students" - A Medical Student Perspective [Letter]
}

This article was published in the following Dove Press journal:

Advances in Medical Education and Practice

Sara Mirza (D)

Shazmin Ahmed (D)

Sulaiman Hayat (D)

King's College London, GKT School of Medical Education, London, UK
Correspondence: Sulaiman Hayat King's College London, GKT School of Medical Education, London SEI 9RT, UK Email sulaiman.hayat@kcl.ac.uk

\section{Dear editor}

We read with interest the recent article by Almari et $\mathrm{al}^{1}$ regarding intrinsic motivation (IM) and extrinsic motivation (EM) in the context of medical student involvement in research. The study found that medical students who engaged in research were more likely to report EM. As fourth- year medical students studying at King's College London, who have undertaken an intercalated BSc and extra-curricular research, we commend what this article delineates and would like to offer our viewpoint.

Currently, the UK Foundation Programme (UKFP) application score consists of up to 7 additional points relating to research; a maximum of 5 for an additional degree and 2 for publications. The percentage of applicants seeking additional points has increased from $30 \%$ to $70 \%$ in the most recent application round. ${ }^{2}$ As penultimate-year medical students, we have experienced the pressure of achieving these points to make our applications competitive. With incredibly narrow deanery cut-off scores, the difference of one point could determine our two-year placement for foundation training and subsequently the likelihood of being allocated our preferred specialties. For us and many of our peers, the extra points are currently the main motivator to get involved in research, and we relate to the senior medical students in this study who were influenced by the looming deadline of intern applications. ${ }^{1}$

However, it was agreed last year by the UKFP board for these 7 additional points to be excluded from the application, with effect from 2023. In a survey of 515 UK medical students, $51 \%$ uncovered that their main motivation to undertake research was career progression. ${ }^{3}$ This suggests that with the removal of EM, there is a high probability that the proportion of medical students who pursue research will decrease. The GMC states that medical school graduates must be able to demonstrate their ability in various research skills, which has been shown to improve one's ability to make evidence-based decisions in clinical practice. ${ }^{4}$ Consequently, with the potential drop in research engagement, we strongly agree with the author's recommendations for future studies to explore promoters of IM, as this can ensure future clinicians do not lack vital skills that undertaking research can foster. 
Pertinently, quantity does not necessarily mean quality. Hence, we put forth the idea that future studies should also explore whether EM and IM have an impact on the quality of research undertaken. We recommend exploring motivations of medical students who have published research and correlating this with the impact factor of the journals they have published in, which has been shown to be a reasonable indicator of quality for medical journals. ${ }^{5}$ This could highlight whether the type of motivation affects the quality of research being produced.

To conclude, we wait in intrigue for the potential impacts of changes to the UKFP regarding additional points, and what they mean for the motivations of future doctors. In addition, further research in this area is critical as it has the potential to improve the quality of research being produced, ultimately guiding clinical practice and bettering patient care.

\section{Disclosure}

The authors report no conflicts of interest for this communication.

\section{References}

1. Alamri Y, Monasterio E, Beckert L, Wilkinson TJ. Intrinsic vs extrinsic motivation as drivers for early engagement in research by medical students. Adv Med Educ Pract. 2021;12:189-194. doi:10.2147/AMEP. S295909

2. UKFPO latest statement sent to medical schools for circulation: Removal of Educational Achievements for entry UKFP 2023. 2020.

3. Griffin MF, Hindocha S. Publication practices of medical students at British medical schools: experience, attitudes and barriers to publish. Med Teach. 2011;33(1):e1-e8. doi:10.3109/0142159X.2011.530320

4. Ibrahim Abushouk A, Nazmy Hatata A, Mahmoud Omran I, Mahmoud Youniss M, Fayez Elmansy K, Gad Meawad A. Attitudes and perceived barriers among medical students towards clinical research: a cross-sectional study in an Egyptian medical school. J Biomed Educ. 2016;2016:1-7. doi:10.1155/2016/5490575

5. Saha S, Saint S, Christakis DA. Impact factor: a valid measure of journal quality? J Med Libr Assoc. 2003;91(1):42-46.

Dove Medical Press encourages responsible, free and frank academic debate. The content of the Advances in Medical Education and Practice 'letters to the editor' section does not necessarily represent the views of Dove Medical Press, its officers, agents, employees, related entities or the Advances in Medical Education and Practice editors. While all reasonable steps have been taken to confirm the content of each letter, Dove Medical Press accepts no liability in respect of the content of any letter, nor is it responsible for the content and accuracy of any letter to the editor.

\section{Publish your work in this journal}

Advances in Medical Education and Practice is an international, peerreviewed, open access journal that aims to present and publish research on Medical Education covering medical, dental, nursing and allied health care professional education. The journal covers undergraduate education, postgraduate training and continuing medical education including emerging trends and innovative models linking education, research, and health care services. The manuscript management system is completely online and includes a very quick and fair peer-review system. Visit http://www.dovepress.com/testimonials.php to read real quotes from published authors. 